\title{
Pediatric tracheostomy: epidemiology and characterization of tracheal secretion - a literature review
}

\author{
iD Caroline Espíndola de Barros ${ }^{1}$ \\ (iD) Iuliana Afonso de Almeida ${ }^{1}$ \\ (iD) Mariana Helena e Silva ${ }^{2}$ \\ D Gustavo Henrique da Silva Ayres² \\ (iD) Camilla Gabriela de Oliveira ${ }^{3}$ \\ Carla Afonso da Silva Bitencourt Braga ${ }^{4}$ \\ (iD) Melissa Ameloti Gomes Avelino
}

\begin{abstract}
1. Programa Ciências da Saúde da Faculdade de Medicina da Universidade Federal de Goiás, Goiânia, GO, Brasil 2. Graduação Biomedicina pela Universidade Federal de Goiás, Goiânia, GO, Brasil 3. Médica Otorrinolaringologista pela Universidade Federal de Goiás, Goiânia, GO, Brasil 4. Professora da Universidade Federal de Goiás (Instituto de Patologia Tropical e Saúde Pública, Goiânia, GO, Brasil
\end{abstract} 5. Professora da Universidade Federal de Goiás (Faculdade de Medicina), Goiânia, GO, Brasil

http://dx.doi.org/10.1590/1806-9282.65.12.1502

\section{SUMMARY}

INTRODUCTION: Despite the benefits, tracheostomized children are susceptible to respiratory infections, since the tube is located in a strategic region where there is colonization by several bacteria and biofilm formation. Biofilm is formed when the bacteria adhere strongly to the surfaces of the tubes, providing protection against various types of aggression, such as antibiotic treatment.

OBJECTIVE: To carry out a literature review of the last ten years on tracheostomized pediatric patients, in order to characterize the bacteria isolated in children's tracheal secretions, and verify which ones are the most frequent.

METHODS: Two authors searched the Lilacs, SciELO, Medline Plus, and PubMed databases. The MeSH terms used were: 'tracheostomy' and 'tracheotomy' associated with 'infections', 'children', 'child', and 'bacterial' as qualifiers.

RESULTS: Of the 512 studies on the subject, 19 were selected for review. The total number of children evaluated in the studies was 4,472, with a mean age of 7.5 years. As for the bacteria found in the secretions of tracheostomized children, 12 species of bacteria were more frequent, P. aeruginosa was the predominant bacterium, followed by S. aureus (63.1\%), Klebsiella pneumoniae (57.8\%), Streptococcus pneumoniae (47.3\%), and Stenotrophomonas maltophilia (47.3\%).

CONCLUSION: One of the main complications treated in tracheostomized patients were infections, since the respiratory system is colonized by several bacteria that can cause serious infections, which are associated with the formation of biofilms. The predominant bacterium in most of the studies was P. aeruginosa, and the second species commonly reported was S. aureus.

KEYWORDS: Child. Trachea. Infection. Biofilms. Pseudomonas aeruginosa. Staphylococcus aureus.

\section{INTRODUCTION}

Tracheostomy is a procedure that opens the airways by inserting a tube into the tracheal rings, allowing air to reach the lungs. The practice of tracheostomy has been reported since ancient times, for more than 2,000 years, and was described by the Egyptians through antique paintings ${ }^{1}$. Between the 1980s until mid-1990s, the indications for tracheostomy underwent great changes, since upper

DATE OF SUBMISSION: 29-MaY-2019

DATE OF ACCEPTANCE: 29-Jul-2019

CORRESPONDING AUTHOR: Caroline de Barros

Instituto de Patologia Tropical e Saúde Pública - Universidade Federal de Goiás - R. 235, S/n

Setor Universitário, Goiânia, GO, Brasil, 74605-450.

Email: carol.barros2@hotmail.com 
respiratory tract infections (URTI), such as diphtheria, were one of the most common reasons for performing the procedure. With the implementation of new immunization programs, the epidemiological profiles of infections have changed, which reduced the need for the procedure ${ }^{2}$. Currently, the indications for tracheostomy are acute respiratory failure, prolonged intubation, neurological disorders or lesions; the first two are the most common. Such indications increase the survival of children, especially of newborns, which results in an increased frequency of the procedure in pediatric patients ${ }^{1,3}$.

Despite the benefits, children who undergo tracheostomy are more susceptible to respiratory infections. The presence of the tube diverts the air passage from the nasal and oral cavities, which provide natural protection, and creates a direct doorway for micro-organisms to enter the lower respiratory tract. The mucociliary clearance of the nasal mucosa and coughing, which clean the lower airways by expelling secretions and possible intruding agents, are also absent in these cases. Similarly, the long-term presence of the tube causes an inflammatory reaction of the tracheal mucosa, which increases the risk of infection since this is a strategic location for the colonization of several bacteria and for biofilm formation ${ }^{4-6}$.

Biofilm is easily formed in this region because bacteria adhere strongly to the surfaces of tubes, forming a matrix that confers protection against various types of attacks, such as from the action of the immune system and antibiotics, which results in subsequent infections with greater frequency ${ }^{5}$. Bacterial pneumonia, aspiration pneumonia, and bacterial tracheitis were the pathologies reported with greater frequency in children who underwent tracheotomy, and bacterial pneumonia was for the highest number of hospitalizations ${ }^{7}$.

The tracheostomy cannula is an environment with favorable conditions for the growth of Pseudomonas aeruginosa (P. aeruginosa), and a direct doorway, due to the incision of the trachea, for colonization by Staphylococcus aureus (S. aureus). These species are found with greater frequency in tracheostomy tubes, but other micro-organisms have been reported too ${ }^{2,4,5,8}$.

There is a clinical difficulty to identify the etiological agent involved in respiratory infections of tracheotomy patients, because tracheal secretion cultures also show colonizing bacteria, and are usually indicated when the child is already under an infectious pro$\operatorname{cess}^{6,9,10}$. However, there is a need for greater caution in relation to the tracheal cultures in children who use a tracheotomy tube given that, in certain circumstances, they have some type of comorbidity or are hospitalized in Intensive Care Units, which makes them vulnerable to infections. In these cases, the culture and antibiogram are of extreme importance to guide appropriate treatment ${ }^{1,2,4,6,11}$.

Due to the above, the objective of this study was to carry out a review of the literature of the past ten years on tracheotomy pediatric patients in order to characterize the bacteria found in tracheal aspirates.

\section{METHODS}

A literature review was conducted in the Latin America and Caribbean Health Sciences Literature (Lilacs), SciELO, National Library of Medicine (Medline Plus), and PubMed databases.

In the Medline and PubMed databases, the MeSH terms "tracheostomy" and "tracheotomy" were used associated with "infections", "children", "child", and "bacterial" as qualifiers.

On the SciELO, Lilacs, and Cochrane databases, we used combinations of the terms "tracheostomy" and "tracheotomy", "infections", "children", "child", and "bacterial".

The articles were evaluated independently by two of the authors of the study. The inclusion criteria for article selection were: English, Portuguese, or Spanish language, published over the past ten years (20082018), with participants aged from 0 to 15 years who used a tracheostomy tube, as well as studies that characterized the tracheal aspirates.

The exclusion criteria were: editorials, guidelines, advice, opinions, reviews, reports and case series, theses, as well as duplicate articles. We also excluded studies that did not evaluate the tracheal secretion, as well as studies on animals, studies of viral infections, studies with different types of samples, and studies that did not specify which samples were from tracheotomy patients.

\section{RESULTS}

During the research, we found 512 studies related to the subject, of which 19 were used for the review. The flowchart of the inclusion process is presented in Figure 1.

The total number of children evaluated in the studies selected was 4,472 , with an average age of 
7.5 years. The studies were conducted in 13 different countries, and the United States had the largest number of cases. Regarding gender, there was a $84 \%$ prevalence of males. With respect to the infection rates, 13 studies reported this index, of which two reported $100 \%$ of infection, six a rate higher than $50 \%$, and the others a rate lower than $50 \%$ (Table 1).

All 19 studies described the bacteria found in the secretions of children who underwent tracheotomy. Twelve types of bacteria were more frequent and are described in Figure 3. P. aeruginosa was the most predominant bacteria, referenced in all studies, followed by S. aureus (63.1\%), Klebsiella pneumoniae (57.8\%), Streptococcus pneumoniae (47.3\%), and Stenotrophomonas maltophilia (47.3\%).

The bacteria found less frequently were Proteus mirabilis and Morganella morganii, mentioned in only two studies (Figure 2).

\section{DISCUSSION}

We found in the present review several reports of tracheostomy in pediatric age patients, especially in children younger than 12 months ${ }^{1,6,16,19}$, because the procedure is directly related to the increase of survival both of premature newborns with congenital malformations and of children of other ages who require mechanical ventilation for any particular purpose.
FIGURE 2. THE MAIN BACTERIA ISOLATED FROM TRACHEAL SECRETIONS OF CHILDREN WITH TRACHEOSTOMY TUBES REPORTED IN STUDIES ACCORDING TO THE AUTHORS.

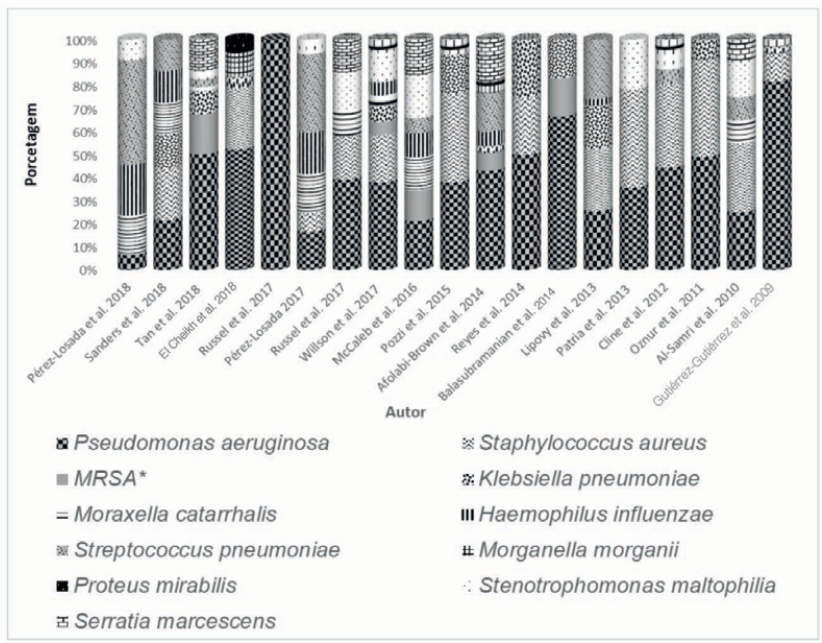

In relation to gender, from a total of 19 studies, 16 reported tracheotomy procedures with a greater frequency in male children ${ }^{1,3,4,6-15,17-20}$. This finding reflects the susceptibility of the gender to genetic or acquired diseases that require tracheostomy, which was also reported in another study on congenital diseases ${ }^{9}$.

Several studies have cited the infections as the major complications in children who undergo

FIGURE 1. FLOWCHART OF STUDY SELECTION FOR LITERATURE REVIEW OF CHILDREN WHO UNDERWENT TRACHEOTOMY.

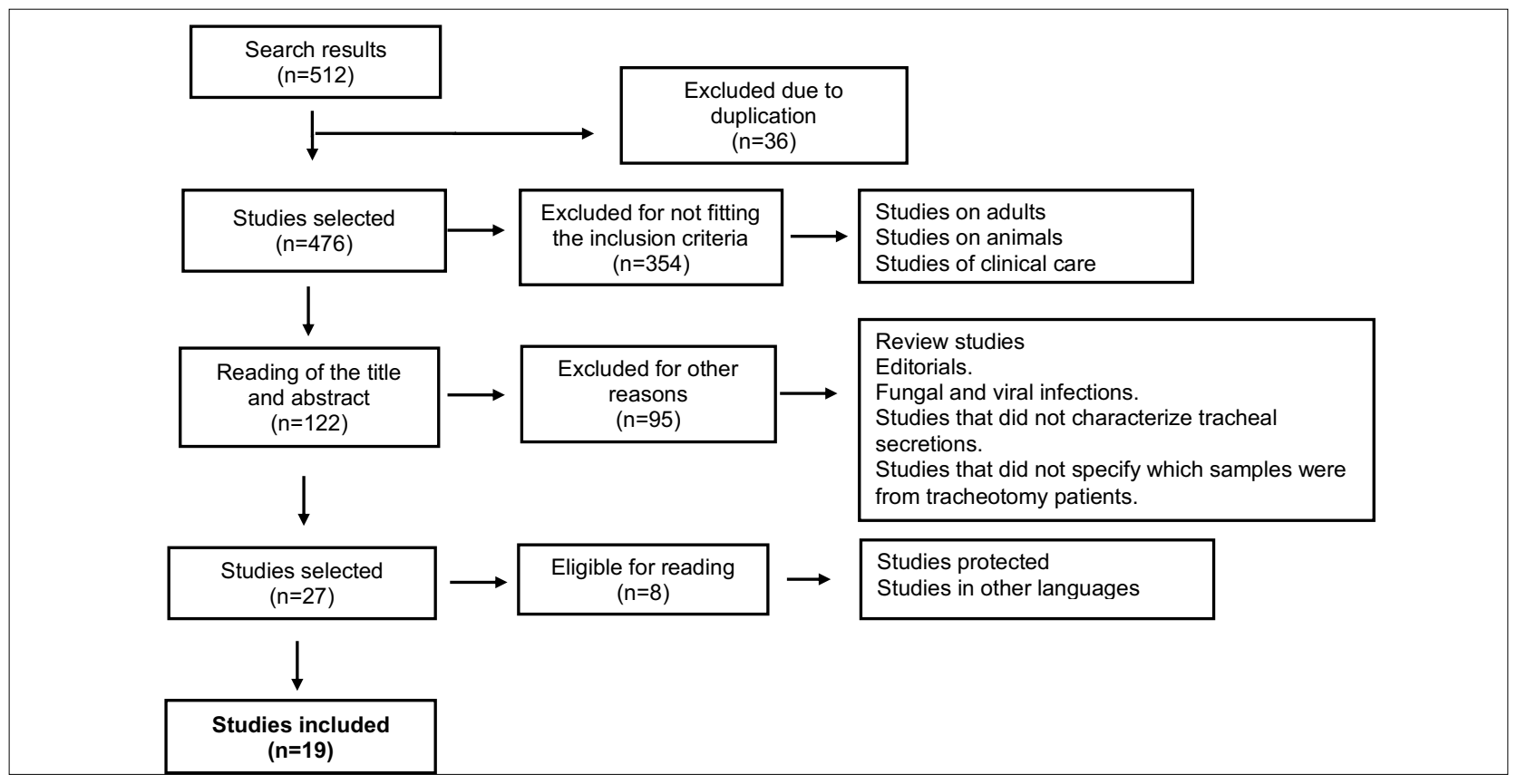


TABLE 1. CHARACTERISTICS OF THE STUDIES INCLUDED IN THE LITERATURE REVIEW OF CHILDREN WHO UNDERWENT TRACHEOTOMY.

\begin{tabular}{|c|c|c|c|c|c|c|}
\hline Author & Country & $\begin{array}{l}\text { Year of publi- } \\
\text { cation }\end{array}$ & $\mathrm{n}$ & Average age & Male & Infection \\
\hline El Cheikh et al. ${ }^{9}$ & Brasil & 2018 & 20 & $2.8 \pm 3.6 \mathrm{y}$ & $65 \%$ & $\mathrm{NE}$ \\
\hline Pérez-Losada et al. ${ }^{12}$ & Spain & 2018 & 20 & $12 \mathrm{y}$ & $70 \%$ & $\mathrm{NE}$ \\
\hline Sanders et al. ${ }^{5}$ & Colombia & 2018 & 185 & $1.15 \mathrm{y}$. & $\mathrm{NE}$ & $68 \%$ \\
\hline Tan et al. ${ }^{6}$ & China & 2018 & 90 & $4.97 \mathrm{~m}$ & $65 \%$ & $47 \%$ \\
\hline Russell et al. ${ }^{12}$ & USA & 2017 & 3103 & $3 y$ & $57 \%$ & $100 \%$ \\
\hline Pérez-Losada et al. ${ }^{3}$ & USA & 2017 & 40 & $12.5 \mathrm{y}$ & $73 \%$ & $50 \%$ \\
\hline Russell et al. ${ }^{7}$ & USA & 2017 & 103 & $\mathrm{NE}$ & $60 \%$ & $100 \%$ \\
\hline Willson et al. ${ }^{13}$ & USA & 2017 & 104 & $5.9 \mathrm{y}$ & $78 \%$ & $\mathrm{NE}$ \\
\hline McCaleb et al. ${ }^{8}$ & USA & 2016 & 93 & $0.84 \mathrm{y}$ & $57 \%$ & $71 \%$ \\
\hline Pozzi et al. ${ }^{14}$ & Italy & 2015 & 65 & NE & $60 \%$ & $51 \%$ \\
\hline Afolabi-Brown et al. ${ }^{15}$ & USA & 2014 & 20 & $12.7 \pm 8.9 \mathrm{y}$ & $65 \%$ & $\mathrm{NE}$ \\
\hline Salcedo et al. ${ }^{1}$ & Cuba & 2014 & 14 & $2.5 \mathrm{y}$ & $71 \%$ & $71 \%$ \\
\hline Balasubramanian \& Tullu ${ }^{16}$ & India & 2014 & 19 & $9 \mathrm{~m}$ & $8 \%$ & $\mathrm{NE}$ \\
\hline Lipový et al. ${ }^{2}$ & Czech Republic & 2013 & 31 & $1.7 \mathrm{y}$ & NE & $\mathrm{NE}$ \\
\hline Patria et al. ${ }^{17}$ & Italy & 2013 & 115 & $4.5 \mathrm{y}$ & $51 \%$ & NE \\
\hline Cline et al. ${ }^{4}$ & USA & 2012 & 170 & $5.5 \mathrm{y}$ & $61 \%$ & NE \\
\hline Ak et al. ${ }^{18}$ & Turkey & 2011 & 83 & NE & $59 \%$ & $26 \%$ \\
\hline Al-Samri et al. ${ }^{19}$ & United Arab Emirates & 2010 & 72 & $3.4 \mathrm{~m}$. & $60 \%$ & $90 \%$ \\
\hline Gutiérrez-Gutiérrez et al.20 & Costa Rica & 2009 & 125 & $5.5 \mathrm{y}$ & $66 \%$ & $36 \%$ \\
\hline
\end{tabular}

m.: months. y:: years. USA: USA: United States of America. NE: Not evaluated.

tracheostomy, especially when there is prolonged use since the tube causes irritation of the trachea and facilitates bacterial colonization, predisposing the development of respiratory infections ${ }^{1,5,19}$.

In the review of studies that characterized the bacteria in tracheal secretions, $P$. aeruginosa was the most prevalent ${ }^{1-9,13-20}$. Sanders et al. ${ }^{5}$ highlight that children who use tracheotomy tubes for long periods are commonly colonized by $P$. aeruginos $a$, and in their study, there was an increase in the isolation of the bacteria after the use of tracheostomy. It is important to emphasize that the presence of the tube provides a direct link to the environment and that the protection mechanism of the upper respiratory tract is ineffective in such cases. In addition, $P$. aeruginosa is an environmental bacterium often found in hospital environments, and due to its great capacity to form biofilms, mainly in plastic devices such as tracheostomy tubes, its control is extremely important to prevent or avoid future complications ${ }^{7}$. It is worth noting that almost half of the studies reviewed (47.3\%) were performed on children admitted to hospitals or Intensive Care Units (ICU) 1,2,4,6,7,14,16-18.

$S$. aureus was the second most frequently reported bacteria in in secretions from the trachea ${ }^{1,2,4,5,9,11,13,14,17-20}$. Despite being a bacteria that colonizes the respiratory tract and skin, it can become pathogenic and lead to serious infections, especially in patients with prolonged use of the tracheostomy tube $^{9}$. S. aureus is associated with several diseases, mainly due to the ease of its transmission, as well as to the various mechanisms of resistance to antibiotics, such as resistance to methicillin and vancomycin. Its participation in infectious processes is also related to its ability to form biofilms, especially in chronic cases, which is an aggravating factor for therapeutic success ${ }^{21}$.

The biofilm is formed with the adherence of bacteria to abiotic (plastics and metals) or biotic (tissue and cells) surfaces, developing a community surrounded by a polymeric extracellular matrix that confers protection against various types of attacks ${ }^{22}$. When we consider that the material of the studies reviewed is a biomedical device, implanted in a strategic region of the patient, such as the trachea, the reversible adhesion between bacteria and surface is favorable to the direct formation of a biofilm ${ }^{23}$. Such formation provides protection against the immune system response, antibiotics, lack of nutrients or water, among others ${ }^{22}$. Thus, the formation of biofilm represents a major 
concern in the treatment and management of patients with a tracheotomy tube, mainly due to the difficulty of antibiotic action on these communities.

There are several mechanisms that hinder antimicrobial activity, since the presence of the polymeric matrix of the biofilm hinders the physical penetration of antibiotics. With this, there is a delay in their dissemination; bacteria in a biofilm present reduced metabolic and growth rates due to the nutrient limitation, which makes the action of medication more difficult, since most medications act when the bacteria are in the process of cell division $^{22}$ and the resistant bacteria present in a biofilm are able to degrade or inactivate antibiotics before they act in sensitive bacteria. In addition to these factors, phagocytes also have difficulty in destroying the micro-organisms because their entry into the matrix of the biofilm is extremely difficult ${ }^{24}$. All these factors show the vulnerability of antibiotics faced with a biofilm.

There is scarce information to guide professionals in the diagnosis and treatment of respiratory infections in children with tracheostomy tubes. It is known that the diagnosis can be achieved by X-ray of the thorax, but it can also be based on clinical criteria, such as increased tracheal secretions accompanied by fever with tachydyspnea. In addition, there is a difficulty in establishing the etiologic agent involved in respiratory diseases since cultures of tracheal secretions are indicated in severe cases, in which there is a need for hospitalization. It is known that among the pathogens of the respiratory system are, in addition to bacteria, viruses, and fungi. To detect specifically what etiological agent is causing the infection is a challenge and essential to implement the appropriate therapy $y^{3,6,9,10,11 .}$

Regarding the control of respiratory infections in patients with tracheostomy tubes, an important measure is to regularly change the cannula, which, according to the literature, should be done monthly in order to avoid the formation of biofilm, which, in turn, can lead to infections of the lower respiratory tract ${ }^{10}$.

Given the relationship between tracheostomy and infections, more studies are needed on the subject to differentiate colonization from infection, and it is essential to standardize the prognosis, diagnosis, and appropriate therapy to control diseases associated with the tracheotomy patients.

\section{CONCLUSION}

Despite the numerous benefits of tracheostomy, studies show there are several complications related to it. The main complication addressed is infection. The predominant bacteria found in most studies was the $P$. aeruginosa, a species with a great capacity to cause respiratory infections, and its treatment can be hampered by its ability to form a biofilm. The second species frequently reported in tracheal secretions was S. aureus, which can also lead to respiratory complications due to the procedure.

There were other species of bacteria reported in tracheal secretions, such as Klebsiella pneumoniae, Streptococcus pneumoniae, and Stenotrophomonas maltophilia.

\section{Contribution of the authors}

All authors participated equally in the development of this work.

\section{RESUMO}

INTRODUÇÃo: Apesar dos benefícios, crianças traqueostomizadas estão suscetíveis a adquirir infecções respiratórias, pois o tubo se encontra em uma região estratégica, na qual existe colonização de diversas bactérias e formação de biofilme. O biofilme é formado quando as bactérias aderem fortemente às superfícies dos tubos, conferindo proteção contra diversos tipos de agressões, como o tratamento por antibióticos.

OBJETIVO: Realizar uma revisão de literatura dos últimos dez anos sobre pacientes pediátricos traqueostomizados, no intuito de caracterizar as bactérias isoladas em secreções traqueais de crianças, verificando-se quais são as mais frequentes.

MÉTOdos: Dois autores pesquisaram nas bases de dados do Lilacs, SciELO, Medline Plus e PubMed. Termos MeSH utilizados: tracheostomy e tracheotomy usados associados a infections, children, chlid e bacterial como qualificadores.

RESULTADOS: Dos 512 estudos relacionados ao tema, 19 foram selecionados para a revisão. O total de crianças avaliadas nos estudos foi de 4.472, com idade média de 7,5 anos. Quanto às bactérias encontradas nas secreções de crianças traqueostomizadas, 12 espécies de bactérias foram mais frequentes; P. aeruginosa foi a bactéria predominante, seguida de S. aureus (63,1\%), Klebsiella pneumoniae (57,8\%), Streptococcus pneumoniae (47,3\%) e Stenotrophomonas maltophilia (47,3\%).

CONCLUSÃo: Umas das principais complicações abordadas em pacientes traqueostomizados foram as infecções, já que o sistema respiratório é colonizado por diversas bactérias, que podem causar infecções graves, sendo estas associadas à formação de biofilmes. A bactéria predominante na maioria dos estudos foi a P. aeruginosa, e a segunda espécie comumente relatada foi a S. aureus.

PALAVRAS-CHAVE: Criança. Traqueia. Infecção. Biofilmes. Pseudomonas aeruginosa. Staphylococcus aureus. 


\section{REFERENCES}

1. Salcedo C, Martínez M, Reyes E. Pediatric tracheostomy: a ten-year analysis in the Intensive Care Unit of Sancti Spiritus "José Martí" Pediatric Teaching Hospital. Medwave. 2014;14(4):e5949.

2. Lipový B, Brychta P, Řihová H, Suchanek I, Hanslianová M, Cvanová M, et al. Effect of timing of tracheostomy on changes in bacterial colonisation of the lower respiratory tract in burned children. Burns. 2013;39(2):255-61.

3. Pérez-Losada M, Graham RJ, Coquillette M, Jafarey A, Castro-Nallar E, Aira $M$, et al. The temporal dynamics of the tracheal microbiome in tracheostomised patients with and without lower respiratory infections. PLoS One. 2017;12(8):e0182520.

4. Cline JM, Woods CR, Ervin SE, Rubin BK, Kirse DJ. Surveillance tracheal aspirate cultures do not reliably predict bacteria cultured at the time of an acute respiratory infection in children with tracheostomy tubes. Chest. 2012;141(3):625-31.

5. Sanders CD, Guimbellot JS, Muhlebach MS, Lin FC, Gilligan P, Esther CR Jr. Tracheostomy in children: epidemiology and clinical outcomes. Pediatr Pulmonol. 2018;53(9):1269-75.

6. Tan CY, Chiu NC, Lee KS, Chi H, Huang FY, Huang DT, et al. Respiratory tract infections in children with tracheostomy. J Microbiol Immunol Infect. 2018. pii: S1684-1182(18)30284-6.

7. Russell C), Simon TD, Mamey MR, Newth CJL, Neely MN. Pseudomonas aeruginosa and post-tracheotomy bacterial respiratory tract infection readmissions. Pediatr Pulmonol. 2017;52(9):1212-8.

8. McCaleb R, Warren RH, Willis D, Maples HD, Bai S, O'Brien CE. Description of respiratory microbiology of children with long-term tracheostomies. Respir Care. 2016;61(4):447-52.

9. El Cheikh MR, Barbosa JM, Caixêta JAS, Avelino MAG. Microbiology of tracheal secretions: what to expect with children and adolescents with tracheostomies. Int Arch Otorhinolaryngol. 2018;22(1):50-4.

10. Avelino MAG, Maunsell R, Valera FCP, Lubianca Neto JF, Schweiger C, Miura CS, et al. First Clinical Consensus and National Recommendations on Tracheostomized Children of the Brazilian Academy of Pediatric Otorhinolaryngology (ABOPe) and Brazilian Society of Pediatrics (SBP). Braz | Otorhinolaryngol. 2017;83(5):498-506.

11. Russell C], Mack WJ, Schrager SM, Wu S. Care variations and outcomes for children hospitalized with bacterial tracheostomy-associated respiratory infections. Hosp Pediatr. 2017;7(1):16-23.

12. Pérez-Losada M, Graham RJ, Coquillette M, Jafarey A, Castro-Nallar E,
Aira $M$, et al. Tracheal microbiota in patients with a tracheostomy before, during, and after an acute respiratory infection. Pediatr Infect Dis I. 2018;37(11):e269-71.

13. Willson DF, Hoot M, Khemani R, Carrol C, Kirby A, Schwarz A, et al; Ventilator-Associated INfection (VAIN) Investigators and the Pediatric Acute Lung Injury and Sepsis Investigator's (PALISI) Network. Pediatric ventilator-associated infections: the ventilator-associated infection study. Pediatr Crit Care Med. 2017;18(1):e24-e34.

14. Pozzi M, Pellegrino P, Galbiati S, Granziera M, Locatelli F, Carnovale $C$, et al. Prevalence of respiratory colonisations and related antibiotic resistances among paediatric tracheostomised patients of a long-term rehabilitation centre in Italy. Eur J Clin Microbiol Infect Dis. 2015;34(1):169-75.

15. Afolabi-Brown O, Marcus M, Speciale P, Pagala M, Kazachkov M. Bronchoscopic and nonbronchoscopic methods of airway culturing in tracheostomized children. Respir Care. 2014;59(4):582-7.

16. Balasubramanian $P$, Tullu MS. Study of ventilator-associated pneumonia in a pediatric intensive care unit. Indian J Pediatr. 2014;81(11):1182-6.

17. Patria MF, Chidini G, Ughi L, Montani C, Prandi E, Galeone C, et al. Ventilator-associated pneumonia in an Italian pediatric intensive care unit: a prospective study. World J Pediatr. 2013;9(4):365-8.

18. Ak $O$, Batirel $A$, Ozer $S$, Çolakoğlu S. Nosocomial infections and risk factors in the intensive care unit of a teaching and research hospital: a prospective cohort study. Med Sci Monit. 2011;17(5):PH29-34.

19. Al-Samri M, Mitchell I, Drummond DS, Bjornson C. Tracheostomy in children: a population-based experience over 17 years. Pediatr Pulmonol. 2010;45(5):487-93.

20. Gutiérrez-Gutiérrez I, Solano-Blanco FP, Gutiérrez-Schwanhauser JB. Original experiencia de la clínica de traqueostomía del Hospital Nacional de Niños "Dr. Carlos Sáenz Herrera". Acta Med Costarric. 2009;51(4):215-21.

21. Bhattacharya M, Wozniak DJ, Stoodley P, Hall-Stoodley L. Prevention and treatment of Staphylococcus aureus biofilms. Expert Rev Anti Infect Ther. 2015;13(12):1499-516.

22. Costerton JW, Stewart PS, Greenberg EP. Bacterial biofilms : a common cause of persistent infections. Science. 1999;284(5418):1318-22.

23. Dunne WM Jr. Bacterial adhesion : seen any good biofilms lately? Clin Microbiol Rev. 2002;15(2):155-66

24. Simões M, Simões LC, Vieira MJ. Species association increases biofilm resistance to chemical and mechanical treatments. Water Res. 2009;43(1):229-37. 